\title{
The Tools of Mathematics Learning Based on Realistic Mathematics Education Approach in Elementary School to Improve Math Abilities
}

\author{
Non Syafriafdi ${ }^{1, *}$, Ahmad Fauzan ${ }^{1}$, I Made Arnawa ${ }^{1}$, Syafri Anwar ${ }^{1}$, Wahyu Widada ${ }^{2}$ \\ ${ }^{1}$ The Doctoral Program of Education, Universitas Negeri Padang, Indonesia \\ ${ }^{2}$ Postgraduate Program of Mathematics Education, Universitas Bengkulu, Indonesia
}

Copyright $C 2019$ by authors, all rights reserved. Authors agree that this article remains permanently open access under the terms of the Creative Commons Attribution License 4.0 International License

\begin{abstract}
The purpose of study was to develop a Mathematics learning tool based on a realistic, valid and effective mathematical approach to improve the ability of fraction concepts. This is part of the research \& development which has three stages, and they are: (1) Preliminary research, (2) Prototyping, including (a) designing, (b) formative evaluation, and (c) prototype revision, and (3) Assessment. The instruments were test of the fraction concept ability, and questionnaire of motivation. The analysis of data was the inferential and descriptive statistics. The results is that realistic mathematical learning tools were feasible to apply and were easy to use, easy to understand and very helpful for the learning process. The learning tool could strengthen students' motivation. The conclusion was that as for the ability of understanding fraction concepts, students who use realistic mathematical learning tools is higher than students who learn conventionally. Thus, a real-time mathematics-learning tool can replace conventional learning.
\end{abstract}

Keywords Learning Tool, Realistic Mathematics Education, Faction Concepts

\section{Preliminary}

Mathematics does not become an interesting learning yet for most students and even Mathematics sometimes becomes one of the scariest lessons. This fact is extracted from the observation result while serving as an elementary school teacher. Most teachers rarely associate the Mathematics material with the real life or everyday life when presenting Mathematics learning [1]. However, teachers tend to deliver the existing learning material [2]. As an illustration, the teachers present the formulas and then ask the students to take notes and finally instruct the students to do the tasks.

For example, achieving the principle of dividing two fractions [2]. For example, 11/2: $1 / 4=$ ? One example of getting a pattern that brings students to be able to achieve the principle that the division of two fractions is a repetitive reduction. This requires learning mathematics that is close to the culture [3]. Therefore, to achieve it begins with something that is close to the mind of the student first, namely the horizontal mathematical process and then continued by the vertical mathematical process so that the principle to be achieved is achieved [2].

The mathematics learning requires students to communicate actively, both verbal and written communication [4]. Therefore, realistic mathematics learning is needed for students [5]. Such learning which using the ethnomathematics approach that applies local culture can change people's perceptions of the application of mathematics in everyday life [6][7].

To improve children's competence in mastering Mathematics, a teacher must be able to relate Mathematics to students' real life. Heruman (2010) argued that in conceptual Mathematics learning, the students need having the understanding that can be obtained through the teaching aids and media. This means that the teacher not only instructs students to memorize formulas but also asks them to interpret the formula by linking it to real life. If the students interpret the material without linking it with their daily life experiences, students will quickly forget and cannot apply mathematics [8].

According to Widada, [2] the use of contextual learning media that is appropriate and in accordance with needs can improve students' abilities in the process of achieving mathematical concepts and principles as well as improving student mastery learning. Contextual learning media can effectively produce patterns (patterns) that students can easily compile initial statements (conjecture) and with vertical mathematical activity, students with the help of more capable friends or teachers can master the concepts 
and principles they are learning. More than $82 \%$ of students are able to understand concepts and principles correctly. $78 \%$ of students are able to arrange definitions and theorems appropriately. The average level of mastery learning reached $86.5 \%$.

According to Traffers and Goffree, [9] the context has four benefits, namely: (1) the formation of concepts: experienced and motivating students were given access in an effort to build mathematical concepts. Contextual problems in mathematics learning are packaged meaningfully to construct mathematical concepts or be manipulated so that students are able to naturally rediscover mathematical concepts; (2) model development: the context plays a role in efforts to develop the ability of students to find strategies to find / rediscover or develop mathematical concepts / principles. (3) application: shows how a mathematical concept can be built in reality or used in everyday life. Reality is a source of mathematical learning and at the same time is the purpose of applying a number of mathematical concepts or principles; (4) training special abilities in application situations: an ability to identify, generalize, and modeling things that play an important role in dealing with applied situations.

In mathematics learning, the teachers do not only teach the conceptual mathematics theory but also need to link it with the real things [10]. It is expected that mathematics learning becomes more meaningful, and easy to understand for students, especially for elementary school-age students who still need to be built the concepts through the real examples [11]. Thus, it is necessary to develop Mathematics learning tool that is valid, practical and effective based on Realistic Mathematics Education approach in elementary school. Realistic Mathematics Education is one of the approaches in Mathematics learning. Realistic Mathematics Education is developed based on Hans Freudenthal's [12] in which he argued that mathematics is a human activity and must be linked with the reality. It is in line with [12] the idea that mathematics must be correlated with reality and Mathematics is a human activity. Therefore, Mathematics should be taught as an activity and not as a thing that has already been done, that mathematics as a subject in schools must be taught as human activities, not as ready-use products. Furthermore, [13] Gravemeijer explained that the part of Mathematics that can be classified as the activities include solving the problems, finding the problems, and organizing the main problem. The related realistic Mathematics, in this case, is Mathematics as the school subject associated with reality and students' experience as the starting point of learning. Realistic problems are used as the sources of the concepts of Mathematics or the formal knowledge of mathematics.

In general, [14]Treffers claimed that there are four approaches to Mathematics learning: mechanistic, structuralist, empirical, and realistic. To implement realistic approaches, the principles of Realistic Mathematics Education need to be understood. Furthermore, Gravemeijer [13] suggested three main principles of Realistic Mathematics Education: (1) reinvention and progressive mathematization, which means the guided discovery and increasing mathematical process, (2) didactical phenomenology, which refers to a phenomenon having a didactical characteristic, and (3) self-developed model that means a model developed by itself.

To support the learning by using the Realistic Mathematics Education approach, it needs the existing tool. The learning tool is an important thing for a teacher since it is a need in carrying out the learning activity. The learning tool is a device or equipment to carry out a particular process that enables teachers and students to be involved in learning activities [2].

\section{Method}

This research is a part of Research and Development (R\&D) study. Plomp [15] asserted that R\&D consists of 3 stages, namely: (1) the preliminary research stage, (2) the prototype stage, and (3) the assessment stage. The detailed stages of R\&D can be seen in Table 1.

Table 1. The Stages of Developing Mathematics Learning Tools Based on Realistic Mathematics Education Approach

\begin{tabular}{|c|c|c|c|}
\hline No & $\begin{array}{l}\text { Development } \\
\text { Stages }\end{array}$ & Activity & Specific activities conducted in research \\
\hline \multirow{5}{*}{1} & \multirow{5}{*}{$\begin{array}{l}\text { Preliminary } \\
\text { Research }\end{array}$} & \multirow{3}{*}{ Needs and context analysis } & Analyzing the characteristics of teachers \\
\hline & & & Analyzing the characteristics of students \\
\hline & & & Analyzing the Mathematics lesson \\
\hline & & Review of literature & $\begin{array}{l}\text { Analyzing the related theory and concept of Realistic } \\
\text { Mathematics Education }\end{array}$ \\
\hline & & $\begin{array}{l}\text { Development of conceptual and theoretical } \\
\text { framework for the study }\end{array}$ & Designing the conceptual framework for development study \\
\hline \multirow{3}{*}{2} & \multirow{3}{*}{ Prototyping Stage } & Design prototype & $\begin{array}{l}\text { Designing Mathematics learning tool with Realistic } \\
\text { Mathematics Education approach }\end{array}$ \\
\hline & & Formative evaluation & $\begin{array}{l}\text { Conducting validity and practicality tests by experts and } \\
\text { practitioners toward the prototype }\end{array}$ \\
\hline & & Revision & $\begin{array}{l}\text { Conducting the revisions for prototype based on formative } \\
\text { evaluation result }\end{array}$ \\
\hline 3 & Assessment Stage & Summative evaluation & Conducting the test and effectiveness of prototype \\
\hline
\end{tabular}


In the implementation stage, we employed a pretest-postest group design. The learning approach included realistic mathematics and conventional. The subjects of the study were all students in the elementary school, with a sample of 60 students. The sample was selected by the intact group technique. The realistic mathematics learning approach with learning tools was implemented in the experiment class, and the conventional approach was implemented in the control class. Data collection was carried out by using the instrument of fraction concepts understanding ability, and quesionner of motivation. It was used to measure students' cognitive level of mathematics understanding. Data were analyzed by Analysis Statistical descriptive and inferential.

\section{Results and Discussion}

The research data were analyzed by using descriptive and inferential statistics. In the validation stage, both teacher book and student book were developed in several aspects: (1) instructions, (2) contents, (3) formats, (4) physical form of the books, (5) benefit of the books, and (6) language used in teacher book. The validation results showed the instructions of the book were very valid, meaning that the instructions for using teacher book had been put properly. Thus, the teacher could use the book well because what the teacher must do was clearly stated. Equally, the content of the learning book was considered very valid in which it had been associated with Realistic Mathematics Education approach, so it could help the teachers in delivering the lesson and increasing the learning interest. Furthermore, the book format of teacher book was also considerably valid since teacher book was easy to understand, the packaging was interesting, and the book could be understood by the teacher.

Another aspect was the physical form of teacher book that had also been valid because the physical form of teacher book determined indicators that must be achieved. Likewise, the benefit of teacher book was also valid because it could already measure what must be measured. The last important aspect was the language. Based on the validator assessment, the language aspect had also been valid. Accordingly, it could be concluded that the teacher book was appropriate to use because it met the desired criteria. The criteria were the validity of contents and constructs in teacher book. In the validation stage of the student book, the aspects assessed included content, language, and presentation. After conducting the validation, the validation results of teacher book were found in which the validity of teacher book contents had an average of 3.39 while the student book had 3.40. Accordingly, the contents of both teacher and student book had been valid and very clear. Data of validation test results on teacher book was presented in Table 2 and student book was presented in Table 3.
Table 2. Validation Test Summary of Teacher Book

\begin{tabular}{llcl}
\hline No & Indicators & Average & Criteria \\
\hline 1 & Instructions & 4,00 & Valid \\
\hline 2 & Contents & 3,33 & Valid \\
\hline 3 & Format & 3,14 & Valid \\
\hline 4 & Physical Form & 3,14 & Valid \\
\hline 5 & Benefit & 3,14 & Valid \\
\hline 6 & Language & 3,57 & Valid \\
\hline & Average & 3,39 & Valid
\end{tabular}

Table 3. Validation Test Summary of Student Book

\begin{tabular}{llcc}
\hline No & Indicators & Average & Criteria \\
\hline 1 & Instructions & 3,86 & Valid \\
\hline 2 & Contents & 3,43 & Valid \\
\hline 3 & Format & 3,10 & Valid \\
\hline 4 & Physical Form & 3,14 & Valid \\
\hline 5 & Benefit & 3,29 & Valid \\
\hline 6 & Language & 3,57 & Valid \\
\hline & Average & 3,40 & Valid \\
\hline
\end{tabular}

Practicality test was done to find out the practicality level of Mathematics learning tool when used in the learning process. This activity was carried out to determine the extent of benefits, easiness of use, and efficiency of time in using Mathematics learning tool by teachers and students. Practicality test was done through delivering the questionnaire of practical test of Mathematics learning tool to the teachers and the fifth-grade students. The results of questionnaire filled by teachers and students are about the indicators: easy to understand, enjoy using, the benefits, appearances, the use of language were generally classified as practical categories. The average value of questionnaire items for each indicator was presented in Table 4

Table 4. The Results of Practicality Analysis Questionnaire of Student Responses as Motivation

\begin{tabular}{llcc}
\hline No. & Indicators & Average & Criteria \\
\hline 1 & Easy to understand & $81,67 \%$ & Practical \\
\hline 2 & Enjoy to use & $86,33 \%$ & Very Practical \\
\hline 3 & Benefits & $83,33 \%$ & Practical \\
\hline 4 & Appearances & $84,33 \%$ & Practical \\
\hline 5 & Language Use & $82,00 \%$ & Practical \\
\hline
\end{tabular}

Table 4 shows that learning mathematics with realistic tools can increase student's motivation to $86.33 \%$. It is a very good achievement. During this time, students feel that learning mathematics is just compulsion. Students feel they only fulfill curriculum obligations. However, by using realistic mathematics learning tools, students are increasingly enthusiastic about learning. They find it easier to learn mathematics $(81.67 \%)$, and earning mathematics is useful $(83.33 \%)$, appearances from realistic learning media are very good and practical $(84.33 \%)$, and using 
easy-to-understand language ( $82.00 \%)$.

The effectiveness of Mathematics learning tool products based on Realistic Mathematics Education approach could be seen from two aspects: (1) student learning motivation, and (2) student learning outcomes. To find out the effectiveness of these products, it would be carried out in the experimental class. Before analyzing data of the experimental class and control class, the requirements test was first carried out for the analysis, namely the normality test and data homogeneity test. From the normality test and data homogeneity test in the experimental class and control class, it was found that both classes were normally distributed and had homogeneity data. For student learning motivation, it was found that their motivation was considered better by using learning tool based on Realistic Mathematics Education approach. It was similar to student learning outcomes that also experienced an increase. The inferential statistic was the used to test difference of the fraction concepts ability in pre-test and post-test. An analysis was carried out by using the t-test that could be seen in Table 5.

Table 5. Comparison of Pre-test and Post-test Values of Control and Experimental Class

\begin{tabular}{ccccc}
\hline \multirow{2}{*}{ Description } & \multicolumn{2}{c}{ Pre-test } & \multicolumn{2}{c}{ Post-test } \\
\cline { 2 - 5 } & $\begin{array}{c}\text { Control } \\
\text { Class }\end{array}$ & $\begin{array}{c}\text { Experimental } \\
\text { Class }\end{array}$ & $\begin{array}{c}\text { Control } \\
\text { Class }\end{array}$ & $\begin{array}{c}\text { Experimental } \\
\text { Class }\end{array}$ \\
\hline Mean & 62,00 & 62,5 & 52,00 & 81,67 \\
\hline $\begin{array}{c}\text { Standard } \\
\text { Deviation }\end{array}$ & 10,95 & 12,37 & 19,01 & 14,22 \\
\hline
\end{tabular}

Analysis of t-test data was carried out at the significance level $=0.05$ with testing criteria if tcount $\leq$ ttable $=$ Ho. If a significance value greater than $=0.05$ is obtained, then, $\mathrm{H} 0$ is accepted. This means that there is no difference in the mathematics learning outcomes of students, who apply realistic mathematics learning devices (experimental class) with the control class. Complete results about the $t$ test based on the test results of the experimental class students (classes using realistic mathematical devices) and the control class (classes that do not use realistic mathematical devices) can be identified with a significance value of $0,000<0.05$. Thus, $\mathrm{H} 0$ is rejected, meaning there are differences in learning outcomes experimental class students (classes that use realistic mathematical devices) with students who use conventional learning devices (control classes). This data shows that learning devices in the form of teacher books and student books with realistic mathematics education developed can be said to be effective.

The results of this study support the conclusions of [16], that is mathematical understanding of students taught by using realistic mathematics learning was higher than those who were taught by using the conventional method (the learning materials in both groups was non-ethnomathematics oriented). Second, mathematical understanding of students learned the ethnomathematics- oriented materials were higher than those who learned non-ethnomathematics-oriented materials (realistic mathematics learning applied in both groups). Third, mathematical understanding of students who learned the ethnomathematics-oriented materials was lower compared to the students who learned the non-ethnomathematics materials (the conventional learning method applied in both groups). Other than that, according to [17], students solved mathematical problems through mathematization process based on ethnomathematics. Students were aware that Rejang Lebong's ethnomathematics was the starting point of horizontal mathematical activity. Just like the traditional house, the culture was a real problem in understanding geometric concepts, such as 2-dimensional and 3-dimensional geometric figures. In particular, students can discover about the surface area and volume of pyramids, prisms, rectangular prism, and cubes. The students' metacognition was used to validate the correctness of the formulas. The students' mathematical communication abilities that were taught by taking realistic mathematics learning approaches are higher than those who were taught by adopting traditional learning approaches. Also, the average ability of the students' mathematics communication learned by using the ethnomathematics-oriented material was higher than those who were given non-ethnomathematics [4]. Thus, it is sufficient that realistic mathematics learning tools can positively support the mathematical abilities of elementary school students.

\section{Conclusions}

Based on the results of descriptive and inferential statistical analysis, it can be concluded that: realistic mathematical learning tools were feasible, practical, easy to use, easy to understand and very helpful in the learning process. Realistic mathematics learning tools can increase student motivation. Finally, as for the ability to understand the concept of fractions, students who use realistic mathematics learning tools is higher than students who study conventionally. Thus, a real-time mathematics-learning tool can replace conventional learning.

\section{REFERENCES}

[1] A. Fauzan, D. Slettenhaar, and T. Plomp, "Traditional Mathematics Education vs . Realistic Mathematics Education: Hoping for Changes," Proc. 3rd Int. Math. Educ. Soc. Conf. Copenhagen Cent. Res. Learn. Math., pp. $1-4,2002$.

[2] W. Widada, "Proses Pencapaian Konsep Matematika dengan Memanfaatkan Media Pembelajaran Kontekstual," J. 
Penelit. Pendidik. Mat. dan Sains, vol. 22, no. 1, pp. 31-44, 2015.

[3] D. Herawaty, W. Widada, T. Novita, L. Waroka, and A. N. M. T. Lubis, "Students' metacognition on mathematical problem solving through ethnomathematics in Rejang Lebong, Indonesia," J. Phys. Conf. Ser., vol. 1088, 2018.

[4] W. Widada, D. Herawaty, D. Yanti, and D. Izzawati, "the Student Mathematical Communication Ability in Learning Etnomathematics Orieted Realistic Mathematics," Int. J. Sci. Res., vol. 7, no. 9, pp. 881-884, 2018.

[5] W. Widada, D. Herawaty, and A. N. M. T. Lubis, "Realistic mathematics learning based on the ethnomathematics in Bengkulu to improve students' cognitive level," J. Phys. Conf. Ser., vol. 1088, 2018.

[6] D. Herawaty and W. Widada, "The Influence of Contextual Learning Models and the Cognitive Conflict to Understand Mathematical Concepts and Problems Solving Abilities," Adv. Soc. Sci. Educ. Humanit. Res., vol. 218, no. ICoMSE 2017, pp. 96-102, 2018.

[7] W. Widada, D. Herawaty, A. Falaq, D. Anggoro, A. Yudha, and M. K. Hayati, "Ethnomathematics and Outdoor Learning to Improve Problem Solving Ability," Adv. Soc. Sci. Educ. Humanit. Res. Vol. 295, vol. 295, no. ICETeP 2018, pp. 13-16, 2019.

[8] K. Gravemeijer, "RME Theory and Mathematics," Tools Process. Math. Teach. Educ., pp. 283-302, 2008.

[9] J. De Lange, Mathematics insight and Meaning. Utrech: OW \& OC.

[10] D. C. Webb, H. van der Kooij, and M. R. Geist, "Design Research in the Netherlnds: Introducing Logarithms Using Realistic Mathematics," J. Math. Educ. Teach. Coll., vol. 2, pp. 47-52, 2011.

[11] Zulkardi, "How to Design Mathematics Lessons based on the Realistic Approach?," RME, Realistic Mathematics Education. pp. 1-17, 1999.

[12] F. Hans, Revisiting Mathematics Educational. Dordrecht: Reidel Publising, 1991.

[13] K. Gravemeijer, Developing Realistic Mathematics Education. Utrecht: Freudenthal Institute, 1994.

[14] A. Treffers, "Didactical background of a mathematics programm for primary education," in L. Streefland (ed.), Realis tic Mathematics Education in Primary School, $C D-\beta$ Press / Freudenthal Institute. Utrecht University, Utrecht: Freudenthal Institute, 1991.

[15] T. Plomp and N. Nieveen, "Educational Design Research Educational Design Research," Educ. Des. Res., no. July, pp. 1-206, 2013.

[16] W. Widada, D. Herawaty, and A. N. M. T. Lubis, "Realistic mathematics learning based on the ethnomathematics in Bengkulu to improve students ' cognitive level Realistic mathematics learning based on the ethnomathematics in Bengkulu to improve students ' cognitive level," J. Phys. Conf. Ser., vol. 1088, no. 1, pp. 1-8, 2018.

[17] D. Herawaty, W. Widada, T. Novita, L. Waroka, and A. N. M. T. Lubis, "Students' metacognition on mathematical problem solving through ethnomathematics in Rejang
Lebong , Indonesia Students , metacognition on mathematical problem solving through ethnomathematics in Rejang Lebong, Indonesia," J. Phys. Conf. Ser., vol. 1088, no. 1, pp. 1-7, 2018. 